\title{
Legal implementation of the UNCRC: lessons to be learned from the constitutional experience of South Africa
}

\author{
Ursula Kilkelly \\ Ton Liefaard
}

\begin{abstract}
SUMMARY
The UN Convention on the Rights of the Child ("CRC") is the leading international instrument recognising the human rights of children across all areas of their lives. Amid measures of legal incorporation, giving constitutional expression to children's rights represents a high watermark of legal protection. South Africa was an early mover in this space adopting a strong children's rights provision in the 1996 South Africa Constitution which made children's rights justiciable as part of a Bill of Rights. Over the last two decades, an empowered judiciary and an active community of legal advocates have combined to enable the South African Constitutional Court to create a body of case-law that has provided leadership globally in the recognition and enforcement of the constitutional rights of children.

Against the backdrop of the Convention's $30^{\text {th }}$ anniversary and increased emphasis on the legal implementation of children's rights, this article reflects on the South African experience of using its Constitution to advance children's rights. Using South Africa as a case study, it considers how the potential associated with giving children's rights the highest status in a country's legal system can be maximised. It identifies the lessons to be learned from the South African experience before concluding with a reminder that however dynamic the development of children's rights law, the effectiveness of the CRC's implementation can only ever be measured by the extent to which it improves children's enjoyment of their rights.
\end{abstract}

\section{Introduction}

The UN Convention on the Rights of the Child ("CRC") is the leading international instrument recognising the human rights of children across all areas of their lives. Thirty years after the CRC's adoption, legal, political and societal change in the way children are treated continues to be a challenge. ${ }^{1}$ At the same time, as states parties continue to take steps incorporate the CRC's provisions into national law, ${ }^{2}$ there is some

1 Multiple edited collections have been published providing a wealth of analysis on the Convention's implementation. See for example, Tobin, J. (ed.) The UN Convention on the Rights of the Child. A Commentary. OUP, 2019; Kilkelly, U. and Liefaard, T. (eds) International Human Rights of Children, Springer, 2018; Ruck, M, Peterson-Badali, M. and Freeman M. (eds). Handbook of Children's Rights: Global and Multidisciplinary Perspectives, Routledge, 2017 and Vandenhole, W, Desmet, E. Reynaert, D. Lembrechts, S. (eds) The Routledge International Handbook of Children's Rights Studies, Routledge, 2015;

2 Kilkelly, U. "The UN convention on the rights of the child: incremental and transformative approaches to legal implementation" 23 (2019) The International Journal of Human Rights 323-337.

How to cite: Kilkelly \& Liefaard 'Legal implementation of the UNCRC: lessons to be learned from the constitutional experience of South Africa' 2019 De Jure Law Journal 521-539 http://dx.doi.org/10.17159/2225-7160/2019/v52a30 
evidence that legal and non-legal measures of implementation have begun to improve children's lived experience of their rights. ${ }^{3}$

Giving constitutional expression to children's rights represents a high watermark of legal protection even if, around the world, practice varies from instruments that include limited references to the needs of children to those that recognise children as fully fledged rights holders. ${ }^{4}$ The process of constitutionalising children's rights is complex and dynamic; it starts with the insertion of children's rights into the Constitution and then requires further associated actions to give real meaning to that change. ${ }^{5}$ These include measures to promote children's access to the courts, provide effective remedies where rights have been violated and enable the judiciary and the legal profession to interpret and apply these rights in a progressive manner. ${ }^{6}$ In truth, there are few examples of where such approaches have been a success.

South Africa was an early mover in the domestic incorporation of children's rights. ${ }^{7}$ Building on previous instruments, the 1996 South Africa Constitution contains a strong children's rights provision - Section 28 - the adoption of which represented a "ground-breaking moment in the advancement of children's rights" when for the first time, children's rights were "robustly and comprehensively recognized in the express language of a nation's constitution". Children's rights were made justiciable under the Constitution, making the courts pivotal in the enforcement of the Bill of Rights. ${ }^{9}$ While there was scepticism that the rhetoric would not translate into tangible legal progress for children's rights in South Africa, ${ }^{10}$ early political measures led by President

3 Lundy, L., Kilkelly, U., Byrne, B and Kang, J. The UN Convention on the Rights of the Child: A study of Legal Implementation in 12 Countries, UNICEF UK, 2012.

4 See in particular, Tobin, J. "Increasingly seen and heard: the constitutional recognition of children's rights", 21 South African Journal on Human Rights (2005) 86-126; European Commission for Democracy through Law (Venice Commission) Report on the Protection of Children's Rights: International Standards and Domestic Constitutions (2014), Opinion nº713 / 2013, para 146, available at www.venice.coe.int and O'Mahony, C. "Constitutional Protection of Children's Rights: Visibility, Agency and Enforceability" (2019) 19(3) Human Rights Law Review 1-34.

5 O'Mahony, C. "The Promises and Pitfalls of constitutionalising Children's Rights" in Dwyer (ed), Oxford Handbook of Children and the Law (Oxford: Oxford University Press, 2019) 869-864.

6 Committee on the Rights of the Child, General Comment No. 5 (2003), General measures of implementation of the Convention on the Rights of the Child (arts. 4, 42 and 44, para. 6), 27 November 2003, CRC/GC/2003/5.

7 Binford, W. (2015) “The Constitutionalization of Children's Rights in South Africa”, 60 New York Law School Law Review 333-364, 342.

8 Binford, W., 334.

9 Cameron, $\mathrm{E}$ and Taylor, $\mathrm{M}$ "The untapped potential of the Mandela Constitution" Public Law (2017) 382-407, at 386.

10 See Sloth-Nielsen, J. "The Contribution of children's rights to the reconstruction of society: some implications of the constitutionalisation of children's rights in South Africa" 4 International Journal of Children's Rights (1996) 323-344, at 324. 
Mandela resulted in "substantial and measurable gains". ${ }^{11}$ Over the last two decades, an empowered judiciary and an active community of legal advocates have combined to enable the South African Constitutional Court to create a body of case-law ${ }^{12}$ that "leads the way in recognizing and enforcing the constitutional rights of children. ${ }^{13}$ While progress has not always been smooth, nonetheless South Africa stands out internationally as an exemplar of how constitutional law can be used to advance children's rights.

Against the backdrop of the Convention's $30^{\text {th }}$ anniversary and increased emphasis on the legal implementation of children's rights, this article reflects on the South African experience of using its Constitution to advance children's rights. Using South Africa as a case study, it considers how the potential associated with giving children's rights the highest status in a country's legal system can be maximised. The first part of the article begins by exploring the legal obligations on states parties to implement the Convention, with specific reference to legal and constitutional measures. In the second part, the article introduces the South African case study - the terms of the Constitution and a summary of the case-law of the South Africa Constitutional Court - in an evaluation of the extent to which the standards of the Convention and the recommendations of the Committee on the Rights of the Child have been given effect. The final part identifies the additional lessons to be learned from the unique South African experience before concluding with a reminder that however dynamic the development of children's rights law, the effectiveness of the CRC's implementation can only ever be measured by the extent to which it improves children's enjoyment of their rights. In this respect, South Africa - like many other states parties - still has some distance to travel.

\section{Implementation and Enforcement of the Convention on the Rights of the Child}

The United Nations Convention on the Rights of the Child was adopted by the General Assembly of the United Nations in November 1989. ${ }^{14}$ Renowned for its comprehensive recognition of the rights of the child,

11 Sloth-Nielsen, J. (1996) "Chicken soup or chainsaws: some implications of the constitutionalisation of children's rights in South Africa" Acta Juridica 6-27, at 7.

12 See Skelton, A (2015) "South Africa" in Liefaard, T. and Doek, J.E. (eds) Litigating the Rights of the Child: The UN Convention on the Rights of the Child in Domestic and International Jurisprudence. Springer, 15; Sloth-Nielsen, J. and Kruuse, H. (2013) "A maturing manifesto: The constitutionalisation of children's rights in South African jurisprudence 2007-2012" 21(4) The International Journal of Children's Rights 646-678; see also Sloth-Nielsen, J. in this volume (TBC) and her references to various relevant sources.

13 O'Mahony, C. (2019), at 872.

14 Adopted and opened for signature, ratification and accession by General Assembly resolution 44/25 of 20 November 1989. The Convention entered into force on 2 September 1990, in accordance with article 49. 
the CRC provides minimum legal obligations on states parties with respect to children's enjoyment of their rights in all areas of their lives. ${ }^{15}$ The Convention is based on a contemporary view of childhood, where beyond welfare and paternalism, children are considered to be fully fledged owners of human rights. ${ }^{16}$ In line with other instruments of international human rights law, the CRC shifted the treatment of children from an approach based on pity or charity, to one which imposed clear and enforceable legal duties on states parties to vindicate CRC rights. This is reinforced by Article 4 of the Convention which requires states parties to take all appropriate legislative, administrative and other measures to implement the Convention ${ }^{17}$ and the importance attached by the Committee on the Rights of the Child to making Convention rights enforceable in the national legal system. ${ }^{18}$ According to the Committee:

"Ensuring that all domestic legislation is fully compatible with the Convention and that the Convention's principles and provisions can be directly applied and appropriately enforced is fundamental."19

The Committee has highlighted the value of including children's rights in national constitutions, while explaining that full implementation of these rights may require the adoption of legislative and other measures. ${ }^{20}$ Tobin describes this as a "climate of expectation" that children's rights be given constitutional expression, ${ }^{21}$ rather than anything more prescriptive and in line with this approach, the Committee has welcomed (e.g. South Africa) $)^{22}$ and at times strongly encouraged states (e.g. Ireland) to take such action. ${ }^{23}$ At the same time, it is difficult to argue that giving constitutional status to children's rights is not an "appropriate" measure of implementation under Article $4 .^{24}$ When the Committee has addressed giving constitutional expression to children's rights, it has advocated both a rights-based approach and the inclusion of the general principles (Article 2 on non-discrimination; Article 3 on best interests;

15 Doek, J.E., “The Human Rights of Children: An Introduction” in Kilkelly, U. and Liefaard, T. (eds). International Human Rights of Children. Springer, 2019, 3-29.

16 Verhellen, E. "The Convention on the Rights of the Child: Reflections from a historical, social policy and educational perspective", in Vanderhole et al, 43-59.

17 Sloth-Nielsen, J. (2019), “Monitoring and Implementation of Children's Rights" in: Kilkelly, U. and Liefaard, T., 31-64.

18 UN Committee on the Rights of the Child, General comment no. 5 (2003): General measures of implementation of the Convention on the Rights of the Child, 27 November 2003, CRC/GC/2003/5, para 19.

19 UN Committee on the Rights of the Child, 2003, para 1.

20 UN Committee on the Rights of the Child, 2003, para 21.

21 Tobin, J., 90-91.

22 Committee on the Rights of the Child, Concluding observations of the Committee on the Rights of the Child: South Africa, CRC/C/15/Add.122, para 3.

23 See UN Committee on the Rights of the Child, Concluding Observations: Ireland CRC/C/15/Add. 85 February 4, 1998, para.25 and UN Committee on the Rights of the Child, Concluding Observations: Ireland, CRC/ C/IRL/CO/2, September 29, 2006, para.25.

24 Tobin, J. at 89 
Article 6 on life, survival and development and Article 12 on the right to be heard). ${ }^{25}$

Similarly, in an analysis of European constitutions, the Council of Europe's Venice Commission found that:

“constitutions that express children's rights in a manner reflecting the indivisibility of rights, enshrining the general principles of the CRC, recognising the status of children as rights holders with an entitlement to have those rights vindicated against the state express the highest forms of compliance with international norms."26

Freeman notes that "[r]ights without remedies are of symbolic importance, no more" 27 and for this reason the Committee on the Rights of the Child has placed significant emphasis on the enforceability of children's rights. ${ }^{28}$ According to the Committee: "[f]or rights to have meaning, effective remedies must be available to redress violations". 29 Children are thus entitled to appropriate reparation where breaches of their rights have been found, 30 including compensation and, where appropriate, measures that promote the child's "physical and psychological recovery, rehabilitation and reintegration". 31 Because children's "special and dependent status creates real difficulties for them in pursuing remedies for breaches of their rights", "effective, childsensitive procedures" must be made available to children and their representatives. ${ }^{32}$ According to the Committee, these must include "child-friendly information, advice, advocacy, including support for selfadvocacy, and access to independent complaints procedures and to the courts with necessary legal and other assistance".33

While legal measures are integral to the implementation of the CRC, the Committee has also stressed the importance of non-legal measures, like those that develop a "children's rights perspective throughout Government, parliament and the judiciary". 34 To this end, it has repeatedly reminded that training and capacity building on children's rights for those who work with and for children is integral to the

25 UN Committee on the Rights of the Child, Concluding Observations: Ireland, CRC/C/15/Add. 85 February 4, 1998, para 21.

26 Venice Commission, para 139.

27 Freeman, M. "Why It Remains Important to Take Children's Rights Seriously" International Journal of Children's Rights 15 (2007) 5-23, at 8.

28 See also Tobin, J., at 91

29 UN Committee on the Rights of the Child, (2003), para 24.

30 Liefaard, T. (2019) "Access to Justice for Children: Towards a Specific Research and Implementation Agenda”. 27(2) The International Journal of Children's Rights 195-227.

31 UN Committee on the Rights of the Child, (2003), para 24.

32 UN Committee on the Rights of the Child, (2003), para 24.

33 UN Committee on the Rights of the Child, (2003), para 24

34 UN Committee on the Rights of the Child, (2003), para 12. 
Convention's effective implementation. ${ }^{35}$ Such training must be "systematic and ongoing" and designed to "increase knowledge and understanding of the Convention." 36 The Committee has singled out the "judiciary" 37 in this context in an important reminder of the essential role played by the courts in the enforcement of Convention rights. ${ }^{38}$

In summary, then, the Committee promotes legal implementation of the CRC in three core ways: incorporation of the CRC into domestic law, at constitutional level where possible; making such rights enforceable, providing remedies where rights are breached, and providing systematic children's rights training to those who work in the legal system to promote the advancement of children's rights and access to justice. The next part of this article will examine the extent to which these requirements have been fulfilled in the South African approach. First, section 28 of the South African constitution will be introduced.

\section{Section 28 of the South African Constitution: meeting the expectations of the CRC}

Following South Africa's ratification of the CRC on 16 June $1995,{ }^{39}$ the new Constitution of the Republic of South Africa was adopted in 1996 , with a dedicated and detailed section on children's rights (section 28). ${ }^{40}$ Situated in Chapter 2 of the Constitution, within a comprehensive Bill of Rights, the children's rights provision sits alongside a number of other provisions - including section 26 on housing, section 27 on healthcare and section 29 on education - which also apply to children. ${ }^{41}$ Section 28 on children's rights is a unique constitutional provision, impressive in its

35 See for example, UN Committee on the Rights of the Child, General comment No. 24 (2019) on children's rights in the child justice system, 18 September 2019, CRC/C/GC/24, para 39; , UN Committee on the Rights of the Child, General comment No. 21 (2017) on children in street situations, 21 June $2017 \mathrm{CRC} / \mathrm{C} / \mathrm{GC} / 21$, paras 18, 40 and UN Committee on the Rights of the Child, General comment No. 16 (2013) on State obligations regarding the impact of the business sector on children's rights, 17 April 2013, CRC/C/ CGC/16, para 61 .

36 UN Committee on the Rights of the Child (2003), para 53.

37 UN Committee on the Rights of the Child (2003), para 53

38 Stalford, H. and Hollingsworth, K. (2017). Judging Children's Rights. in: Stalford, H., Hollingsworth, K. and Gilmore, S. (eds), Rewriting Children's Rights Judgments. From Academic Vision to New Practice, Bloomsbury, p. $21 \mathrm{ff}$.

39 See the United Nations Treaty Database, https://treaties.un.org/Pages/ ViewDetails.asp ? $\mathrm{src}=\mathrm{IND \&}$ mtdsg_no $=\mathrm{IV}-11$ \& chapter $=4 \&$ lang $=$ en $\quad$ (last visited 17 June 2019). Skelton, A. (2015) in Liefaard, T. and Doek, J.E, 14.

40 As adopted on 8 May 1996 and amended on 11 October 1996 by the Constitutional Assembly. For a brief drafting history see Sloth Nielsen, J. (1996), 325-328.

41 Skelton, A. (2015), In Liefaard, T. and Doek, J.E. 14 with reference to Friedman, A. Pantazis A., and Skelton, A. (2009). Children's Rights. In: Woolman, S., Roux, T. and Bishop, M. (eds). Constitutional law of South Africa, Cape Town: Juta, pp. 41.1-36). 
simplicity and its scope. It recognises the child's rights: to name and nationality (section 28(1)(a)), family and alternative care (section 28(1)(b)), basic nutrition and healthcare (section 28(1)(c), protection from exploitation and abuse (section 28(1)(e)-(f)) and protection from the arbitrary detention (section 28(1)(g)). In line with Article 1 of the CRC, section 28(3) defines a child as a person under 18 years and in requiring that a child's best interests are of "paramount importance in every matter concerning the child", section 28(2) of the Constitution goes beyond the CRC standard (article 3(1) of which requires that a child's best interests are "a primary consideration"). ${ }^{42}$ Significantly, Section 28(1)(h) provides children with the additional safeguard of the right to be assigned a legal practitioner at state expense in civil proceedings affecting the child, if substantial injustice would otherwise result". This is a unique provision which reinforces the child as a legal actor and in contemplating the child's participation in civil proceedings, reflects an early and progressive understanding of children's access to justice. ${ }^{43}$

By any measure, the content of section 28 is impressive. Judged against the standards of the CRC, and the Committee's recommendation that such provision must be right-based, Tobin notes that the entitlements in the provision "are canvassed in the language of rights and clearly draw their inspiration from the Convention". 44 In terms of substantive content, the breadth of section 28 is strong insofar as it gives expression to a number of socio-economic and civil and political rights, without caveat or condition, reflecting the political consensus that surrounded the adoption of section $28 .{ }^{45}$ The choice of rights appears firmly rooted in the South Africa experience - with emphasis on the child's survival rights of nutrition and shelter for example and more detailed references to the child's right to protection from the harms of economic exploitation and armed conflict. ${ }^{46}$ It is with respect to the Committee's recommendation, that states parties incorporate the Convention's general principles in their national constitutions, that the provision falls short however. The key elements of the Convention's principles in Article 2 (non-discrimination) and Article 6 (right to life, survival and development) can be found elsewhere in the Bill of Rights (e.g. section 9 on equality and section 11 on the right to life as well as in the references in sections 28 and 29 to the cornerstones of the child's development). Thus, the only CRC principle given explicit protection in the Bill of Rights is the best interests of the child. As noted above, section

42 See Bonthuys, E. "The Best Interests of the Child in the South African Constitution" (2006) 20(1) International Journal of Law, Policy and the Family 23-43, 32-33.

43 See generally Liefaard, T. (2019) "Access to Justice for Children: Towards a Specific Research and Implementation Agenda". 27(2) The International Journal of Children's Rights 195-227.

44 Tobin, J., at 112.

45 Sloth-Nielsen, J., (1996), at 326.

46 These provisions also reflected the emphasis in the African Charter on the Rights and Welfare of the Child ratified by South Africa in 2000. See further Binford, at 344-347. 
28(2) requires that the child's best interests are of "paramount importance in every matter concerning the child", representing a stronger formulation than the "primary consideration" approach set out in Article 3 of the CRC. While it is positive that section 28 gives constitutional expression to the best interests principle, there have been concerns, evident in the case-law, about its interplay with the other provisions. ${ }^{47}$ Moreover, the absence of the child's participation rights is a significant omission from section 28 , which makes no reference to the child's right to be heard in all matters that affect him/her as required by Article 12(1) of the CRC. It is very welcome that section 28(1)(h) recognises that the child has a right to legal representation in civil proceedings, if "substantial injustice" would otherwise result. ${ }^{48}$ This echoes the reference to legal representation in Article 12(2) of the Convention. At the same time, the absence of the substantive right of participation means that section 28 falls short of the Committee's recommendations in this area. The articulation of civil rights (unspecified), that apply to children in the other provisions of the Bill of Rights, has been said to create an expectation for the participation of children in political decision-making. ${ }^{49}$ However true, this is a poor substitute for including in the Constitution a child specific right to participation along the lines of 12. Perhaps, a more substantive amelioration of this deficit can be found in section 39(1)(b) of the Constitution, which requires the courts to take account of international law in its interpretation of the Bill of Rights. This gives ample scope to the Constitutional Court to draw on the provisions of the CRC and indeed other instruments such as the African Charter on the Rights and Welfare of the Child to strengthen section $28 .^{50}$ The impact of this provision is considered further below.

The Committee on the Rights of the Child has made clear that constitutional expression of children's rights is of little value without effective mechanisms in place to provide for their enforcement and it is here that the South African Constitution hits the higher water mark of international comparison. In particular, section 7(2) of the South Africa Constitution requires the state to respect, protect, promote and fulfil the rights in the Bill of Rights and section 38 secures the enforcement of these rights before a court, with an entitlement to secure appropriate relief from a court where rights have been breached. ${ }^{51}$ The justiciability

47 See Bonthuys, E. (2006); Skelton, A. (2018). "Child Justice in South Africa: Application of International Instruments in the Constitutional Court". 26(3) The International Journal of Children's Rights 391-422.

48 On aspects of its implementation see Stewart, L. "Resource constraints and a child's right to legal representation in civil matters at state expense in South Africa” 19 The International Journal of Children's Rights (2011) 295320.

49 Viviers, (2012) A. and Lombard, A. "The ethics of children's participation: Fundamental to children's realisation in Africa" 56(1) International Social Work 7-21

50 On the use of this provision, see further Skelton, A. (2018).

51 Skelton, A. (2015), at 13. 
and remedy provisions mean that the South Africa Constitution clearly meets the Committee's expectations in this respect. ${ }^{52}$ It also appears to meet the standards set by the Venice Commission which has recommended that Council of Europe member states put in place efficient mechanisms, judicial and non-judicial, to remedy possible violations of children's rights. ${ }^{53}$

Compared internationally, the children's rights provisions in the South African Constitution are impressive in both substance and enforceability. Tobin's analysis of the world's constitutions concludes, with respect to South Africa, that there are few jurisdictions where children's rights enjoy such explicit protection and fewer still where such rights are justiciable. ${ }^{54}$ O'Mahony, whose assessment of the children's rights provisions of the world's constitutions according to a typology of visibility, agency and enforceability, concludes that "South Africa offers the clearest example internationally of a constitution that scores highly on all three spectrums". ${ }^{55}$ On paper, in almost every material respect, therefore, the South Africa model of constitutional incorporation of children's rights sets the bar high, and thus explicitly echoes the Committee's recommendations on giving constitutional expression to children's rights at national level and doing so on an enforceable rights-basis. The next section of this paper goes on to consider the extent to which this potential has been realised with respect to the development of children's rights jurisprudence by the Constitutional Court and considers in addition what additional lessons can be learned from the South African experience.

\section{Realising the potential of section 28 from a children's rights perspective: the case-law of the Constitutional Court}

There is now extensive case-law from the South Africa Constitutional Court on children's rights matters, with equally comprehensive academic analysis of its merits and scope. ${ }^{56}$ Rather than repeating this analysis

\footnotetext{
52 Tobin, J. at 119.

53 Venice Commission, para 146.

54 Venice Commission.

55 O’Mahony, C. (2019) (in press).

56 See, for example, Sloth-Nielsen, J, in this volume. (TBC); Centre for Child Law (2018). 20 Years of Imagining Children Constitutionally - Strategic Litigation and Advocacy for Children's Rights in South Africa. Pretoria; Skelton, A. (2018); Skelton, A. (2015); Sloth-Nielsen, J. and Kruuse, H.; Sloth-Nielsen, J. and Mezmur, B., " $2=2=5$ : Exploring the Domestication of the CRC in South African Jurisprudence (2002-2006)". 16(1) The International Journal of Children's Rights (2008) 1-28; Robinson, JA, "Children's Rights in the South-African Constitution 6(1) Potchefstroom Electronic Law Journal (2003) 1-58; and Sloth-Nielsen, J. (2002). “Children's rights in the South African courts: An overview since ratification of the UN Convention on the Rights of the Child". 10(2) The International Journal of Children's Rights, 137-156.
} 
here, this article seeks to draw on the literature to review the children's rights case-law from the perspective of the Committee's guidance on Convention implementation.

The first question to address is whether the South Africa case-law reflects a rights-based approach to the determination of children's issues. By all accounts, the first decade of South African constitutional jurisprudence was disappointing in this respect. According to SlothNielsen, claims under section 28 in the early years of the Constitutional Court focused mainly on the rights of parents. ${ }^{57}$ She observes that, in the initial constitutional litigation, children were largely invisible and their constitutional rights were "largely ... harnessed by adults in pursuit of their own claims" whereas "children's individual interests" did not take "centre stage". 58 Identifying one reason for this emphasis, Justice Albie Sachs criticized the practice of failing to hear the voices of the child. In his postscript to the 2000 case Christian Education South Africa v Minister of Education Justice Sachs posited that although the state and the parents were in a position to speak on behalf of children, "neither was able to speak in their name". Denying the children a curator ad litem, who could have made sensitive enquiries, children voices were not heard. Had they been included, Justice Sachs observed, “[children's] actual experiences and opinions ... would have enriched the dialogue, and the factual and experiential foundations for the balancing exercise in this difficult matter would have been more secure". ${ }^{9}$ The absence of the participation principle (article 12) from section 28 was arguably being keenly felt here.

There were also substantive outcomes that were regarded as disappointing from a children's rights perspective. Principal among these was the Grootboom case in which the Constitutional Court took a restrictive approach to the justiciability of the child's rights under section 28(1)(c) of the Constitution (to basic nutrition, shelter, basic health care services and social services). ${ }^{60}$ Here, the Court held that section 28 does not create "any primary obligation to provide shelter on demand to parents and their children if children are being cared for by their parents or families". 61 Accordingly, the Court ruled that "there was no obligation upon the state to provide shelter to those of the respondents who were children and, through them, their parents in terms of section 28(1)(c)". 62 This ruling was heavily criticised for denying children "a preferential

57 Sloth-Nielsen, J, in this volume. (TBC) with reference to Christian Education South Africa v Minister of Education (CCT4/00) [2000] ZACC 11; 2000 (4) SA 757; 2000 (10) BCLR 1051.

58 Sloth-Nielsen, J. in volume (TBC); see also Sloth-Nielsen, J. (2002).

59 Christian Education South Africa v Minister of Education (CCT4/00) [2000] ZACC 11; 2000 (4) SA 757; 2000 (10) BCLR 1051 at 53.

60 Government of the Republic of South Africa and Others $v$ Grootboom and Others (CCT11/00) [2000] ZACC 19; 2001 (1) SA 46; 2000 (11) BCLR 1169 (4 October 2000).

61 Grootboom, at 77.

62 Grootboom, at 79. 
claim to resources" which some suggested represented the true meaning of section $28(1)(\mathrm{c}){ }^{63}$

As the first decade of the 1996 Constitution came to an end, however, the jurisprudence of the Constitutional Court began increasingly to recognise children's interests as self-standing, requiring independent consideration. ${ }^{64}$ Cases such as Centre for Child Law $v$ Minister for Home Affairs $^{65}$ on the interests of migrant children in detention, $A D \vee D W,{ }^{66}$ on intercountry adoption, De Reuck $v$ DPP, ${ }^{67}$ which upheld the ban on possession of child pornography in children's best interests, and Brandt $v S$, ${ }^{68}$ which concerned sentencing of children and the (restrictive) use of deprivation of liberty in this regard, all pointed to a shift in the Court's approach towards a recognition of the child's status as an autonomous rights holder. ${ }^{69}$ At the same time, there was an ongoing tension evident in the case-law of the Constitutional Court between the desire to offer children protection on the one hand and to recognize their autonomy on the other. 70

Importantly, especially in light of the above critique of section 28 in this respect, Sloth-Nielsen and Mezmur noted that the Court's shift towards a more rights-based approach was accompanied by children's views being taken into account. ${ }^{71}$ Legal representation for children and the appointment of curators (ad litem) or amicus curiae to represent the interests of children during the legal proceedings played a significant role in the promotion of a greater child-rights approach in the litigation. ${ }^{72} \mathrm{~A}$ notable increase in public interest litigation, especially under the leadership of the Centre for Child Law, ${ }^{73}$ sometimes including children's

63 Sloth-Nielsen, J. in volume (TBC); see also Nolan, A. (2017). "Commentary on Government of the Republic of South Africa and Others $v$ Grootboom" in: Stalford, H., Hollingsworth, K. and Gilmore, S. (eds), Rewriting Children's Rights Judgments. From Academic Vision to New Practice, Bloomsbury, 311-318.

64 Sloth-Nielsen, J. and Mezmur, B. (2008)..

65 Centre for Child law and Another v Minister of Home Affairs and Others 2005 (6) SA 50 (T).

66 AD and Another v DW and Others (CCT48/07) [2007] ZACC 27; 2008 (3) SA 183 (CC); 2008 (4) BCLR 359 (CC).

67 De Reuck v Director of Public Prosecutions (Witwatersrand Local Division) and Others (CCT5/03) [2003] ZACC 19; 2004 (1) SA 406 (CC); 2003 (12) BCLR 1333 (CC).

68 Brandt v S 2004 JOL 1322 (SCA).

69 Sloth-Nielsen, J. in volume (TBC).

70 See Sloth-Nielsen, J. in volume (TBC); see also later Teddy Bear Clinic for Abused Children and Another $v$ Minister of Justice and Constitutional Development and Another (CCT 12/13) [2013] ZACC 35; 2013 (12) BCLR 1429 (CC); 2014 (2) SA 168 (CC); 2014 (1) SACR 327 (CC).

71 Sloth-Nielsen, J. and Mezmur, B. (2008).

72 Jonas highlights in this respect how "practices and experiences of South Africa where amicus participation has resulted in the phenomenal growth of constitutional jurisprudence." See Jonas, O. "The participation of the amicus curiae institution in human rights litigation in Botswana and South Africa: a tale of two jurisdictions" 59(2) Journal of African Law (2015) 329-354. 
direct involvement, ${ }^{74}$ has over the years had a transformative effect on the substance, as well as the outcome of constitutional jurisprudence on children's rights issues. This is perhaps best illustrated by the landmark case of $S$ v. M (Centre for Child Law as Amicus Curiae) ${ }^{75}$ and the following dictum of Justice Albie Sachs:

\begin{abstract}
"Individually and collectively all children have the right to express themselves as independent social beings, to have their own laughter as well as sorrow, to play, imagine and explore in their own way, to themselves get to understand their bodies, minds and emotions, and above all to learn as they grow how they should conduct themselves and make choices in the wide social and moral world of adulthood. And foundational to the enjoyment of the right to childhood is the promotion of the right as far as possible to live in a secure and nurturing environment free from violence, fear, want and avoidable trauma."76
\end{abstract}

Another strong example, highlighting the potent nature of section 28, is reflected in the following statement from Justice Cameron in Centre for Child Law v Minister for Justice and Constitutional Development and Others:

"The rights the provision secures are not interpretive guides. They are not merely advisory. Nor are they exhortatory. They constitute a real restraint on Parliament. And they are an enforceable precept determining how officials and judicial officers should treat children." 77

Sloth-Nielsen and Kruuse note, with reference to both Justice Sachs' and Justice Cameron's dicta, that "South African courts had begun to construct an image of the "constitutional child", which no longer only focused on children's protection, but included emancipatory elements and a recognition of autonomy rights. ${ }^{78}$ Skelton suggests that this caselaw achieved a balance in " $[\mathrm{t}]$ he approach to children in (South Africa) litigation encompasses both the need to protect children and advance their [autonomy] rights"79 while Sloth-Nielsen similarly concluded that that in the South Africa case-law, “[c]hildren's rights had been employed both as a sword (...) and as a shield". 80

Despite this progress, however, the Constitutional Court has continued to be criticised for reaching for the best interests principle under section

73 See Centre for Child Law (2018).

74 See e.g. Centre for Child Law v Hoerskool Fochville 20162 SA 121 (SCA), as cited in Sloth-Nielsen, J. in volume (TBC).

75 S v M (CCT 53/06) [2007] ZACC 18; 2008 (3) SA 232 (CC); 2007 (12) BCLR $1312(\mathrm{CC})$.

76 S v M (CCT 53/06) [2007] ZACC 18; 2008 (3) SA 232 (CC); 2007 (12) BCLR 1312 (CC), para. 19.

77 Centre for Child Law v Minister for Justice and Constitutional Development and Others (CCT98/08) [2009] ZACC 18; 2009 (2) SACR 477 (CC) ; 2009 (6) SA 632 (CC); 2009 (11) BCLR 1105 (CC), para. 25.

78 Sloth-Nielsen, J. and Kruuse, $\mathrm{H}$, at $671 \mathrm{ff}$.

79 Skelton, A. (2017) Chapter 11: Constitutional protection of Children's Rights. In: Boezaart, T. (ed) Child Law in South Africa, Juta, at 358, as cited by Sloth-Nielsen, J. in volume (TBC).

80 Sloth-Nielsen, J. in volume (TBC). 
28(2) when substantive rights would be more consistent with a rightsbased Convention-compliant view. ${ }^{81}$ Apart from the concern that the courts prefer the more woolly, paternalistic "best interests" principle to an approach that underscores children as the holders of rights, Skelton highlights that this approach deprives children's rights under the Constitution of more explicit consideration and elaboration from the courts. ${ }^{82}$ Perhaps this reflects the tension evident in the children's rights literature between "interests" and "rights", 83 which the Committee on the Rights of the Child has also tried to address. ${ }^{84}$ At the same time, Sloth-Nielsen remarks that the best interests principle has been developed into "a constitutional right, rule of procedure, and a principle" under section 28, meaning that it is "hardly an empty vessel any longer". 85 This is a very good illustration of how working through children's rights issues in the national courts can help to further theoretical thinking about the implementation of children's rights principles. Here, as in other areas, the Constitutional Court has shone a light on how a balance can be struck between protection and welfarism on the one hand, and autonomy, emancipation and participation on the other. ${ }^{86}$

Reflective of the comprehensive nature of the Convention, which recognises children's rights in all areas of their lives, academic analyses of the case-law also highlight the breadth of children's rights issues considered by the Constitutional Court over the years. In their analysis of the Court's jurisprudence, Sloth-Nielsen and Kruuse observe that during 2008 and 2013 the case-law tended to be dominated by issues, among others, on the right to dignity of the child, ${ }^{87}$ the right to education ${ }^{88}$ and

81 Skelton, A. (2018); cf. Couzens, M.M. (forthcoming), The application of the United Nations Convention on the Rights of the Child by national courts, PhD dissertation Leiden University; see also Vandenhole, W. (2015). Belgium. In: Liefaard, T. and Doek, J.E. (eds)., 105-122, who shows that this is an issue of concern elsewhere as well.

82 Skelton, A. (2018).

83 See for example, Kilkelly, U. "The Best interests of the Child: A Gateway to Children's Rights", in Sutherland, E. and Barnes Macfarlane, LA, Implementing Article 3 of the United Nations Convention on the Rights of the Child, Cambridge University Press, 2016, 51-66.

84 Committee on the Rights of the Child, General comment No. 14 (2013) on the right of the child to have his or her best interests taken as a primary consideration (art. 3, para. 1), CRC/C/GC/14, 29 May 2013.

85 Sloth-Nielsen, J. in volume (TBC) with reference to Couzens, M.M. (forthcoming),

86 See e.g. the closing remarks of Sloth-Nielsen in Sloth-Nielsen, J. in volume (TBC).

87 See e.g. S v M (CCT 53/06) [2007] ZACC 18; 2008 (3) SA 232 (CC); 2007 (12) BCLR 1312 (CC), para. 18 in which the court held that "[e]very child has his or her own dignity" and that "[i]f a child is to be constitutionally imagined as an individual with a distinctive personality, and not merely as a miniature adult waiting to reach full size, he or she cannot be treated as a mere extension of his or her parents, umbilically destined to sink or swim with them".

88 Governing Body of the Juma Musjid Primary School v Essay 20118 BCLR 761 (CC). 
the availability of the required resources for children's implementation and remedies in this regard. ${ }^{89}$ Throughout its history, however, the South African Constitutional Court has considered an impressive range of important children's rights issues. For instance, it has considered children's rights in the family, including the right to parental or family care, ${ }^{90}$ the court review of decisions to remove children from their families, ${ }^{91}$ international child abduction, ${ }^{92}$ intercountry adoption ${ }^{93}$ and surrogacy. ${ }^{94}$ Very recently, the Constitutional Court declared the common law defence of reasonable chastisement unconstitutional ${ }^{95}$ but it has also considered the child's right to protection from harm in cases concerning child pornography, ${ }^{96}$ the right to be protected against corporal punishment ${ }^{97}$ and against abuse, ${ }^{98}$ the right to dignity of the child $^{99}$ and the protection of child victims. ${ }^{100}$ The Court has also developed jurisprudence on sensitive issues, such as the rights of children accused of criminal offences, including the prosecution of children for consensual sexual activity ${ }^{101}$ and the right of child sex offenders to be protected from automatic placement on the sex offenders register. ${ }^{102}$ While not limited to children's rights, the Court has

89 Director of Public Prosecutions, Transvaal $v$ Minister for Justice and Constitutional Development and Others (CCT 36/08) [2009] ZACC 8; 2009 (4) SA 222 (CC); 2009 (2) SACR 130 (CC); 2009 (7) BCLR 637 (CC). See further Sloth-Nielsen, J. and Kruuse, H. (2013); see also Sloth-Nielsen, J. in volume (TBC).

$90 S v M$ (CCT 53/06) [2007] ZACC 18; 2008 (3) SA 232 (CC); 2007 (12) BCLR $1312(\mathrm{CC})$.

$91 C$ and Others $v$ Department of Health and Social Development, Gauteng and Others (CCT 55/11) [2012] ZACC 1; 2012 (2) SA 208 (CC); 2012 (4) BCLR 329 (CC).

92 Sonderup v Tondelli and Another (CCT53/00) [2000] ZACC 26; 2001 (2) BCLR 152; 2001 (1) SA 1171.

$93 A D$ and Another $v$ DW and Others (CCT48/07) [2007] ZACC 27; 2008 (3) SA 183 (CC); 2008 (4) BCLR 359 (CC)

94 See e.g. AB and Another v Minister of Social Development [2016] ZACC 43.

95 Freedom of Religion South Africa $v$ Minister of Justice and Constitutional Development and Others [2019] ZACC 34.

96 De Reuck v Director of Public Prosecutions (Witwatersrand Local Division) and Others (CCT5/03) [2003] ZACC 19; 2004 (1) SA 406 (CC); 2003 (12) BCLR 1333 (CC).

97 Christian Education South Africa v Minister of Education (CCT4/00) [2000] ZACC 11; 2000 (4) SA 757; 2000 (10) BCLR 1051 (18 August 2000).

98 Geldenhuys $v$ National Director of Public Prosecutions and Others (CCT 26/08) [2008] ZACC 21; 2009 (2) SA 310 (CC); 2009 (1) SACR 231 (CC); 2009 (5) BCLR 435 (CC).

99 Centre for Child Law v Minister for Justice and Constitutional Development and Others (CCT98/08) [2009] ZACC 18; 2009 (2) SACR 477 (CC) ; 2009 (6) SA 632 (CC); 2009 (11) BCLR 1105 (CC).

100 Director of Public Prosecutions, Transvaal $v$ Minister for Justice and Constitutional Development and Others (CCT 36/08) [2009] ZACC 8; 2009 (4) SA 222 (CC); 2009 (2) SACR 130 (CC); 2009 (7) BCLR 637 (CC).

101 Teddy Bear Clinic for Abused Children and Another $v$ Minister of Justice and Constitutional Development and Another (CCT 12/13) [2013] ZACC 35; 2013 (12) BCLR 1429 (CC); 2014 (2) SA 168 (CC); 2014 (1) SACR 327 (CC).

$102 J v$ National Director of Public Prosecutions and Another [2014] ZACC 13; see also Zita Hansungule, Protecting Child Offenders' Rights. Testing the 
developed extensive jurisprudence on the Constitution's socio-economic provisions addressing the child's rights to housing, healthcare and education and rights to social assistance and inheritance have also been litigated during this time. ${ }^{103}$

Case-law by its nature is incremental and it is evident that the Constitutional Court has been growing in stature and reach since its establishment under the 1996 Constitution. While not necessarily limited to the Constitutional Court (the focus of this present analysis), SlothNielsen concludes that, over the years, children's rights scholars have detected a "growing insertion of children's rights considerations in increasingly diverse areas of legal interaction", reflecting the increased attention to children's rights in areas to which they were perhaps not previously considered relevant. ${ }^{104}$ It is evident that the role of amicus curiae, especially South Africa's Centre for Child Law, had the effect of shining a children's rights light on cases involving and affecting children so that the Constitutional and indeed other courts could better see them from this perspective.

The scope of South Africa's children's rights jurisprudence is impressive, especially insofar as it extends way beyond traditional family and child law matters, into complex and sensitive areas of children's rights such as those highlighted above. Although no one factor has enabled this success, the expression of children's rights in the South Africa Constitution and the establishment of the Constitutional Court with a powerful mandate to enforce those rights have been essential ingredients. Requiring the Court to draw on international instruments like the Convention on the Rights of the Child has been instrumental at times in ensuring that the jurisprudence aligned with South Africa's international obligations. Skelton and others note that the CRC and the ACRWC have been key influences on the Court where they have informed the South African jurisprudence in line with the Bill of Rights' interpretive clause (section 39). ${ }^{105}$

It is also clear that the power to interpret and apply the national constitution has led to children's rights becoming embedded in the domestic legal system. These observations reflect the findings of other international research that has highlighted the benefits to children of "bringing rights home". ${ }^{106}$ In this way, the South African example

constitutionality of the National Register for sex offenders, SA Crime Quarterly, December 2014 (http://dx.doi.org/10.4314/sacq.v50i1.3).

103 For examples see the Grootboom case referred to earlier; see also SlothNielsen, $\mathrm{J}$. in volume (TBC) on the case law (also from other courts than the constitutional court) regarding education; see furthermore Skelton, A. (2017), at 346-347, as cited by Sloth-Nielsen, J. in volume (TBC).

104 Sloth-Nielsen, J. in volume (TBC).

105 Skelton, A. (2015).

106 See Lundy, L., Kilkelly, U., Byrne, B and Kang, J.; Sandberg, K. (2014). "The Role of National Courts in Promoting Children's Rights: The Case of Norway" 22(1) The International Journal of Children's Rights 1-20 and Couzens, M.M. (forthcoming), 
illustrates the value of permitting, if not requiring, the courts to draw on international and regional law in their interpretation of domestic children's rights provisions showing how such approaches can bring a different perspective or a different frame of reference at times. ${ }^{107} \mathrm{~A}$ strong feature of the South Africa experience is that these approaches can be stimulated by strategies of public interest litigation, such as that conducted by the Centre for Child Law, which test the boundaries of legal standing and amicus curiae participation to promote greater access to justice for children. But regardless of the strength of the legal provision and the determination of the litigating parties, it is only with a responsive and informed judiciary, willing to explore new avenues, that real change in children's rights protections can come about. For over two decades now, the South African Constitutional Court has led the development of a "climate" favourable to children's rights and children's rights litigation. ${ }^{108}$ This has not only contributed to specific case-law to advance children's rights at a domestic level, ${ }^{109}$ it has also influenced and inspired the promotion of children's rights and children's rights litigation internationally. ${ }^{110}$ The South African experience clearly highlights that those who litigate, advocate and campaign for children's rights, individually or collectively, play a vital supportive role in the Convention's implementation. ${ }^{111}$

\section{Lessons from the South Africa Constitutional experience}

The preceding analysis shows that South Africa is an exemplar of constitutional incorporation of children's rights, in line with the requirements of the Convention and the guidance of the Committee on the Rights of the Child. The final section of this article reflects on what lessons can be learned from South Africa's constitutional history in order to better protect children's rights in other jurisdictions.

\section{Strength of constitutional expression}

As noted above, the Committee on the Rights of the Child has recommended that where children's rights are given constitutional expression, this should include references to the Convention's general

107 See section 38 of the Constitution; Skelton, 2015, pp. 15-17, with reference to Sloth-Nielsen, J. and Mezmur, B. (2008)., among others.

108 Skelton, A. (2015), at 13.

109 See Sloth-Nielsen, J, in this volume. (TBC); Centre for Child Law (2018); Skelton, A. (2015).

110 See Skelton, A. (2015), at 14 with reference to Alston, P. and Tobin, J. (2005). Laying the Foundations for Children's Rights. Florence: UNICEF Innocenti Research Centre.

111 See generally Liefaard, T. and Doek, J.E. (eds) (2015). Litigating the Rights of the Child: The UN Convention on the Rights of the Child in Domestic and International Jurisprudence, Springer; Kilkelly, U. (2011) "The CRC at 21: Assessing the Legal Impact". Northern Ireland Legal Quarterly, 62 (2):143152. 
principles. Despite the absence of the CRC's participation principle, section 28 nonetheless stands out, in international terms, as a weighty constitutional provision whose detail goes far beyond what the Committee has recommended in other ways. ${ }^{112}$ O'Mahony notes for instance there are few, if any, national constitutions that contain the level of detail found in the Constitution of South Africa. ${ }^{113}$

With respect to the Committee's recommendation that constitutional expression of children's rights must be rights-based, it is significant that, compared with other constitutions, the South African provision is framed unequivocally in rights language. Section 28(1) begins with the phrase: "every child has the right to ..." and thereafter the provision mirrors the approach of the Convention by reinforcing the child's status as an autonomous rights-holder. ${ }^{14}$ It is significant too that this appears to have played an important role in the Court's interpretation and application of section 28 where it draws on the unequivocal rights language in the provision to impose clear obligations on national authorities to vindicate the rights of the child. The fact that the Constitution includes both socio-economic rights (see the references to nutrition, shelter and health care) and civil and political rights (see the right to name and nationality), reflecting the commitment in the Convention to a comprehensive and holistic view of the rights of the child has also been significant in scaffolding the development of a comprehensive body of jurisprudence. By any analysis, then, the breadth of children's rights jurisprudence from the Constitutional Court has been enabled, in the first instance, by the Constitution's detailed, comprehensive and rights-based children's rights provision.

\section{Enforceability and remedies for the breach of children's rights}

The second notable element of the South Africa experience is the power that the South African Constitutional Court has to enforce section 28, using a range of remedies when children's rights are breached. As noted above, the Committee on the Rights of the Child has recommended that enforcement is key to the meaningful protection of children's rights at national level, noting that reparation is key to the vindication of these rights. As considered here and elsewhere, the case-law of the Constitutional Court is wide-ranging and dynamic, addressing a multitude of children's rights issues. In one sense, there can be no better evidence of the fact that section 28 did indeed provide the Court with solid platform on which to build the constitutional law on children's rights. Crucially, however, this case-law goes beyond theoretically interesting or erudite analyses of the law. The Court also, in numerous

112 Tobin, J. (2005); Habashi et al., (2010) "Constitutional Analysis: A Proclamation of Children's Right to Protection, Provision, and Participation”, 18 International Journal of Children's Rights 267.

113 See O'Mahony, C. (2019) (in press).

114 Doek, J.E. (2019), The Human Rights of Children: An Introduction, in: Kilkelly, U. and Liefaard, T. (eds). International Human Rights of Children. Springer, pp. 3-29. 
cases provided remedies for children - individually and collectively whose rights were breached, going beyond providing reparation to individual children to the choice of remedies that go to the heart of children's enjoyment of their rights. Remedies have included the striking down of legislation and ordering compensation for wrongful detention, while also including more creative measures such as requiring childfriendly interpretation of national law, not to mention the substantial gains achieved through out of court settlements and agreements. ${ }^{115}$ This flexible approach to remedies for the breach of children's rights demonstrates how litigating children's rights can be used to benefit children beyond those participating in the litigation, to the advantage of children more generally, all the time staying true to the ultimate goal of vindicating children's rights, meeting children where they are in this process.

\section{Legal training and the awareness of children's rights}

The third important element of the South Africa experience, again drawing on the recommendations of the Committee on the Rights of the Child, has been the existence among the senior judiciary of those with knowledge and awareness of children's rights. As noted above, the Committee has identified that children's rights training for judges is vital for the implementation of the Convention and frequently reminds states parties of the importance of building capacity and raising awareness of those who work with and for children in the legal system. International studies have illustrated the importance of judicial training in the successful implementation of the Convention ${ }^{116}$ and significantly, when the Committee examined the first periodic report of South Africa under Article 44 of the Convention, it welcomed the integration of human rights into the training curriculum for magistrates, and other officials concerned with the administration of justice. ${ }^{117}$ In 2016 , when it next considered South Africa implementation, it specifically welcomed "the progressive application by the judiciary, in the state party's jurisprudence, of the rights and principles stipulated in the Convention". 18 While the role of skilled lawyers has been instrumental in the development in South Africa of an innovative body of children's rights law, it is the combination of this expertise with the demonstrated awareness of and commitment to children's rights by the Constitutional Court that allowed the development of such progressive and expansive children's rights jurisprudence in South Africa. In this respect, South Africa offers a very important illustration of the impact of judicial training

115 Sloth-Nielsen, J. in this volume.

116 See Lundy, L. Kilkelly, U., Byrne, B and Kang, J. (2012); See also Liefaard, T. and Doek, J.E. (eds) (2015).

117 Committee on the Rights of the Child, Concluding observations of the Committee on the Rights of the Child: South Africa, CRC/C/15/Add.122, (2000) para 5.

118 Committee on the Rights of the Child, Concluding observations of the Committee on the Rights of the Child: South Africa, CRC/C/ZAF/CO/2, (2016) para 5. 
- a specific recommendation of the Committee on the Rights of the Child

- on the legal advancement of children's rights at national level.

\section{Conclusion}

From the perspective of the expression and enforcement of children's rights, the South African story is overwhelmingly positive - a strongly worded constitutional provision, whose justiciability has been exploited by skilled lawyers before a progressive judiciary willing to use all the powers of the Constitutional Court to make a difference, where possible, in the protection of children's rights. While the historical context to this development is perhaps unique, there are many lessons for other jurisdictions to learn as to how to give greater constitutional effect to children's rights.

What remains challenging - in South Africa as elsewhere - is the translation of these constitutional children's rights principles into the reality of children's lives. As the 2016 Concluding Observations on South Africa's state party report shows, South Africa's record in the implementation of the Convention is poor, with substantial gaps in the protection and promotion of children's rights across many aspects of their lives. ${ }^{119}$ The Committee's Observations draw attention to the fundamental breaches of children's substantive rights in South Africa, while its recommendations highlight the need for widespread structural and institutional reform designed to secure better protection and promotion of children's rights across the state party. It is difficult not to despair that such inequality and injustice continues to exist in a country with such an impressive and long record in the constitutionalisation of children's rights. Here it is important to remember that the constitutionalising children's rights is the beginning not the end of the journey of giving effect to children's rights and even where the Constitution sets a high watermark, law and policy must also align with the Convention's comprehensive, inclusive and rights-based approach to children's rights if rights are to be translated into the kind of political action that enriches the lives of children in their families and communities. Research has highlighted the value of adopting non-legal measures of implementation, including children's rights budgeting, the allocation of resources, national plans for children and the creation of national human rights institutions as measures capable of building a culture of respect for children's rights that is meaningful and lasting. 120 Only when political and constitutional change combine, therefore, can respect for children's rights be truly transformative. In South Africa, as elsewhere, this is an ongoing process.

119 See Committee on the Rights of the Child, Concluding observations of the Committee on the Rights of the Child: South Africa, CRC/C/ZAF/CO/2, (2016).

120 Kilkelly, U. (2019). 